\title{
THE BENEFICIAL USAGE OF WATER TREATMENT SLUDGE AS POTTERY PRODUCT
}

\author{
A. B. Azinoor Azida ${ }^{1}$, A. Azida, M. A. Wahid ${ }^{2}$ and F. Kamarudin ${ }^{3}$ \\ ${ }^{1}$ Faculty of Civil Engineering, UniversitiTeknologi MARA, Bandar Seri Alam, 81750 Masai, \\ Johor, Malaysia \\ ${ }^{2}$ Faculty of Civil Engineering, UniversitiTeknologi MARA, 40450 Shah Alam, Selangor, \\ Malaysia \\ ${ }^{3}$ Faculty of Civil Engineering, UniversitiTeknologi MARA, 13500 PermatangPauh, Pulau Pinang, \\ Malaysia
}

Published online: 10 November 2017

\begin{abstract}
The disposal of sludge from water treatment operations has become a major problem in Malaysia. The problem becomes acute because of scarcity of space for installation of sludge treatment facilities and disposal of treated sludge. Traditionally, treated sludge from water treatment plant will be sent to landfill for disposal. This method does not benefit anybody besides creating other problems. Instead of considering it as a waste, sludge must be considered as a quality by-product that can be changed into beneficial product for consumer. As a pilot study, this research only emphasize on characterization of water treatment sludge and its behaviour when mixed with clay. Mineralogical compositions were determined using XRD, XRF for chemical composition and physical testing including Atterberg limit test and particles size distribution. Identification of beneficial usage is based on the characteristics of water treatment sludge.
\end{abstract}

Keywords: chemical composition; mineral composition; physical characteristics; pottery product; water sludge.

Author Correspondence, e-mail: azinoor@johor.uitm.edu.my

doi: http://dx.doi.org/10.4314/jfas.v9i6s.42

Journal of Fundamental and Applied Sciences is licensed under a Creative Commons Attribution-NonCommercial 4.0 International License. Libraries Resource Directory. We are listed under Research Associations category. 


\section{INTRODUCTION}

Sludge is a byproduct of water treatment. Sludge was produced during clarification and filtration processes. Sludge was also produced from the accumulated solids removed from sedimentation basin or settling tank. The disposal of sludge from water treatment operations has become a major problem in Malaysia. The problem becomes acute because of scarcity of space for installation of treated sludge. The advantage of water sludge is that this kind of sludge is not a hazardous waste. Many people concern about the constituents of the sludge those that affect our body our body system. This study should continue in finding the product which can be produced from water sludge. Fig. 1 shows the traditional approach for water sludge management. Fig. 2 shows the new approach for water sludge management.

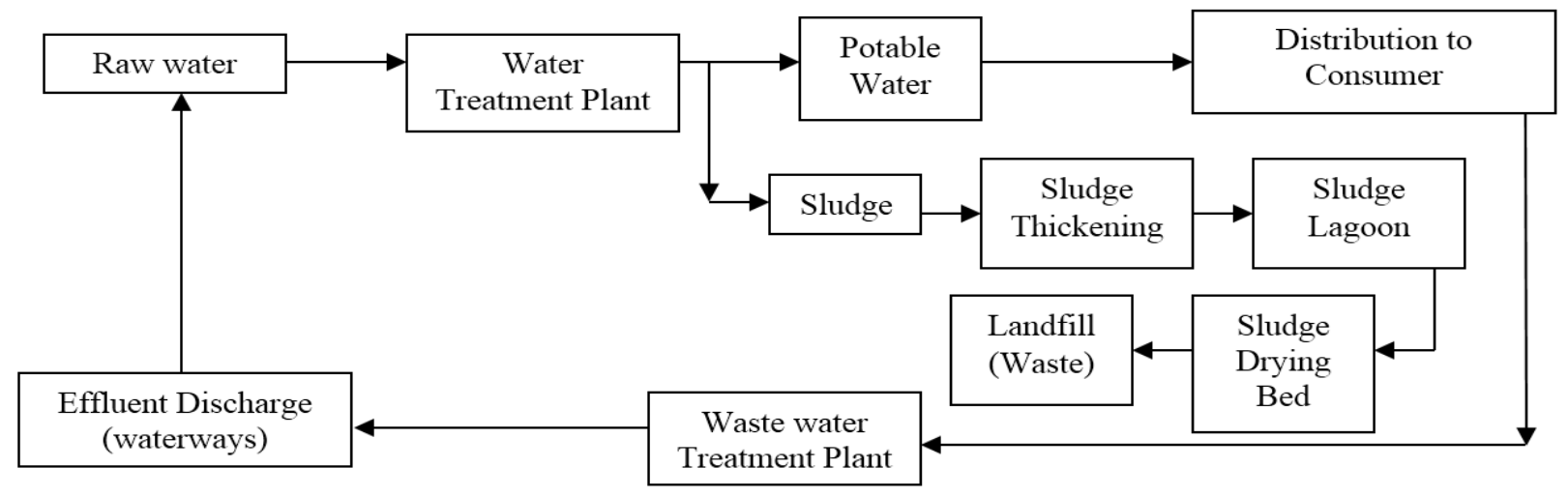

Fig.1. Traditional approach for water sludge management

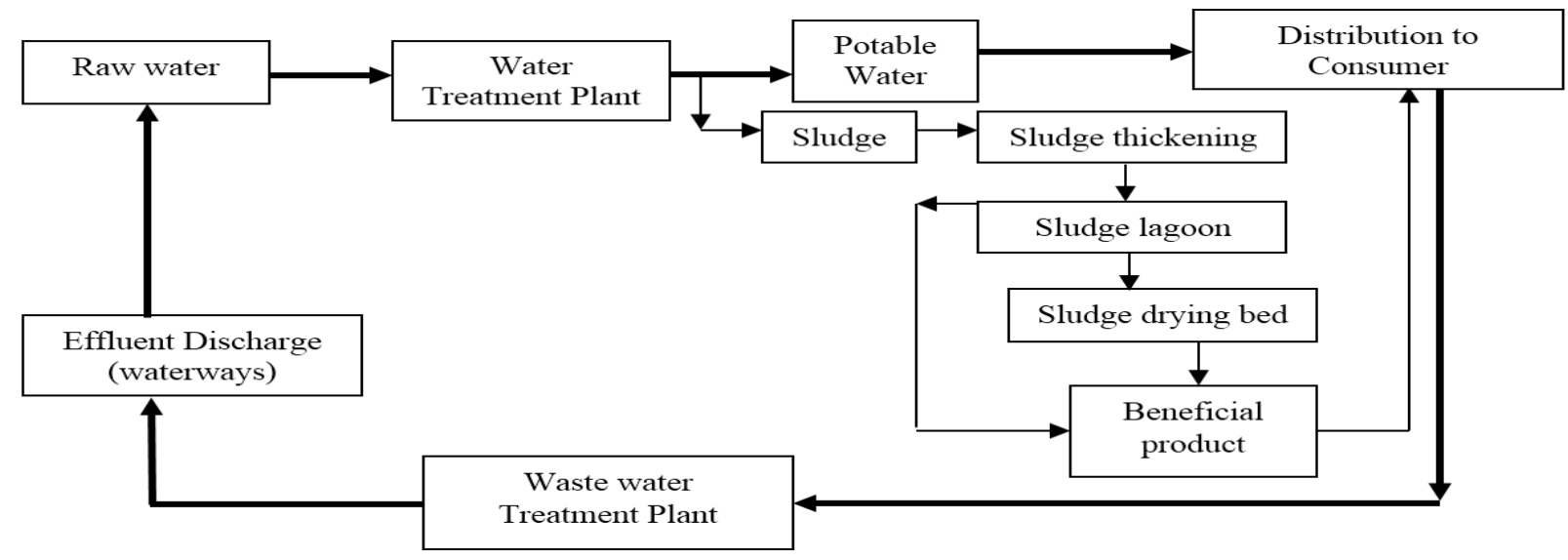

Fig.2. New approach for water sludge management

\section{MATERIALS AND METHODS}

The unit operations and processes for sludge handling in water treatment facilities includes thickening, dewatering, liquid lime treatment and ultimate disposal (as shown in Fig. 3). 


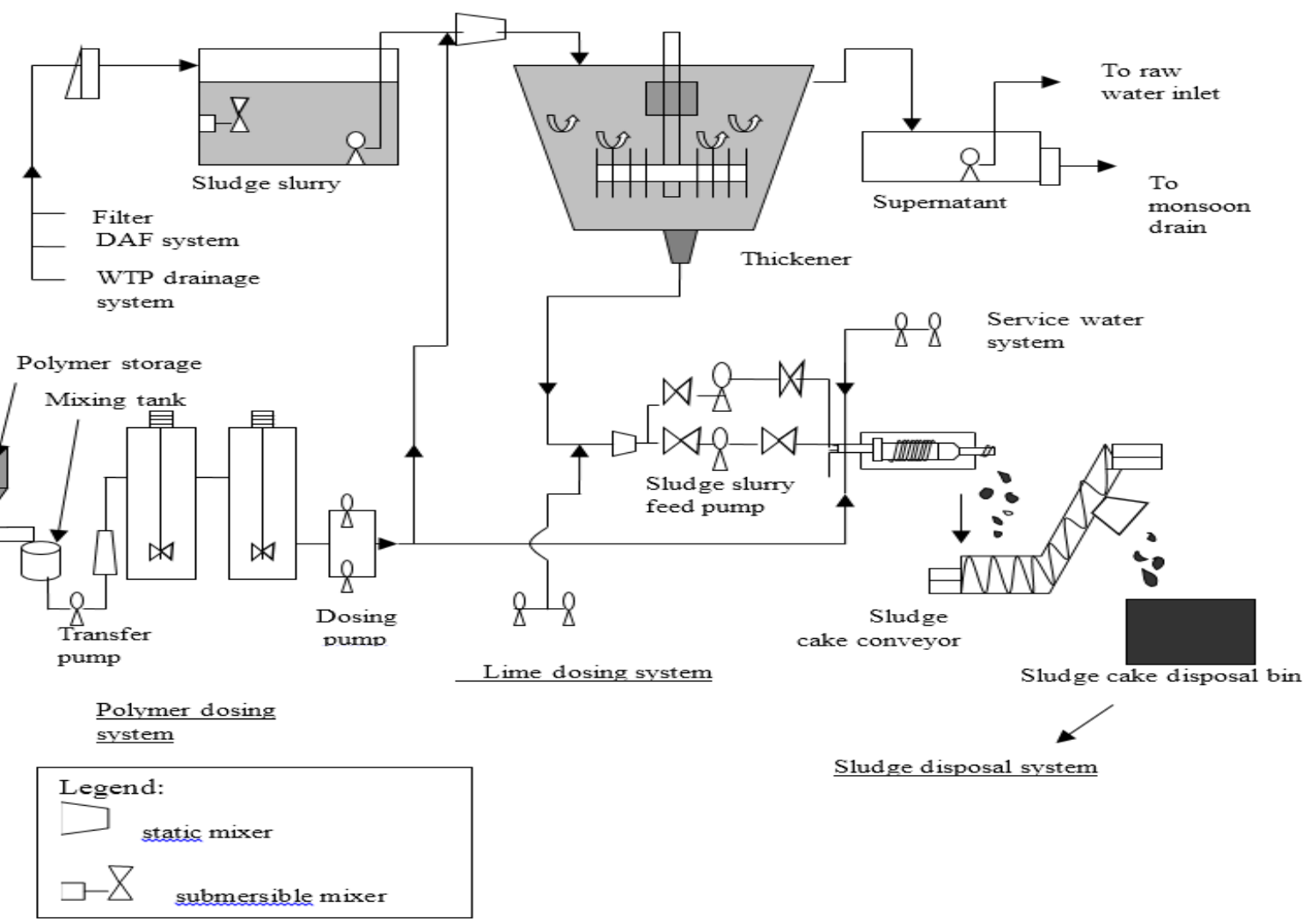

Fig.3. A schematic diagram of sludge treatment

The physical characteristics, mineral compositions and chemical compositions of water treatment sludge are influenced by raw water quality and water treatment processes. Physical properties of sludge include plasticity limit, moisture content and particle size. For pottery making, the plasticity characteristics permit the sludge to be shaped or melded when mixed with water; and they must have sufficient wet and air-dried tensile strength to maintain their shape after forming. Plasticity behaviour and maximum deformation, which depends on moisture content, will be examined using plastic limit and liquid limit test (Attenberg Plasticity limit).The moisture content of samples will be determined by weighing the samples after dried at $110^{\circ} \mathrm{C}$. The percentages of the various grain sizes present in a sludge will be determined by sieving and sedimentation hydrometer test. Finer particles give a smoother and shinier surface than coarser particles [2]. Particles size need for pottery is less than $0.005 \mathrm{~mm}(5 \mu \mathrm{m})$. Colour is an important source of information for sludge (e.g. a red sludge indicates the presence of iron oxide; blue or grey soil indicates the sludge originated from a marsh). Metallic oxides (particularly those of iron, magnesium and calcium) influence the colour of the finished fired product.

The shape, size and specific surface all influence the engineering behaviour of sludge minerals. 
Mineral composition is shown by a chemical formula, which is a shorthand way of indicating the numbers of atoms of different elements that make up the mineral. Mineral composition of the sludge was determined using X-ray Diffraction (XRD).

Chemically, there are compounds of silica and alumina with varying amounts of metallic oxides and other impurities. Although technically metallic oxides are impurities, they act as fluxes, promoting lower temperatures. Chemical composition of the sludge was determined by using X-Ray Fluorescence (XRF) and Total Nitrogen Measurement (TNM). All standard techniques were done as described in British Soil Standard (BS1377-1990) [1].

\section{RESULTS AND DISCUSSION}

\subsection{Mineralogical Composition}

The first feature studied was mineral compositions. Mineral compositions as determined by x-ray diffraction are as follows: Silica, kaolinite, muscovite, iron oxide and iron hydrogen phosphate. Silica is more prominent compared to others [5]. The result is shown in Fig. 4.

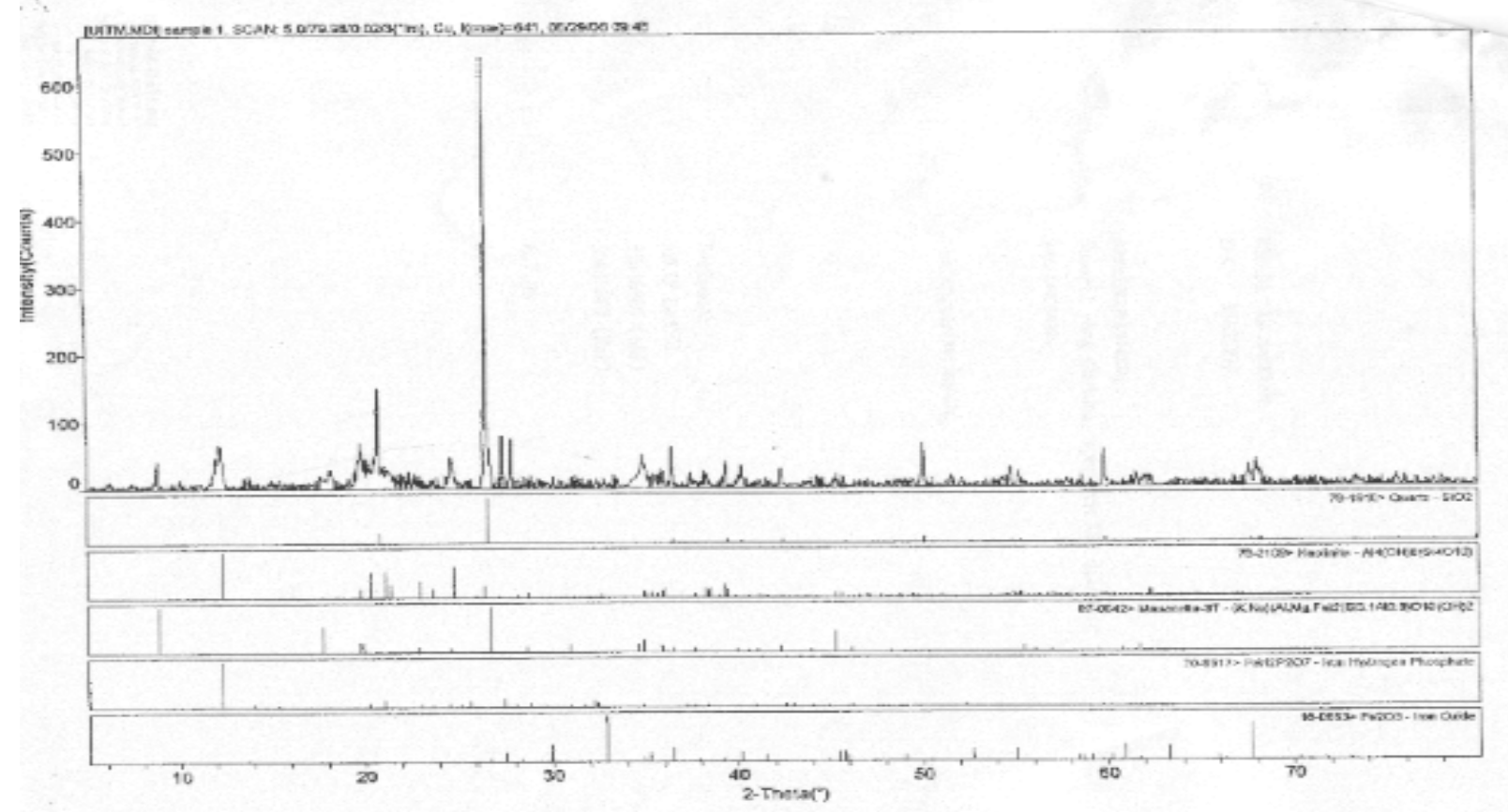

Fig.4. XRD pattern for water treatment sludge 
There are a few forms of silica. The form of free silica $\left(\mathrm{SiO}_{2}\right)$ is found in almost all clays in various forms such as quartz (a constituent of sand, flint and other rocks), tridymite, cristobalite (both formed from quartz geologically or when fired) and amorphous (non-crystalline) silica. Water treatment sludge contained high concentration of free form silica. Refer to [4], for most clay, kaolinite or $\mathrm{Al}_{2} \mathrm{Si}_{2} \mathrm{O}_{5}(\mathrm{OH})_{4}$, aluminium silicate hydroxide is a major component and also sold as 'kaolin'. It is formed from the alteration (mostly weathering) of aluminium rich silicate minerals such as feldspars. Kaolinite is important to the production of ceramics and porcelain. Muscoviteor $\mathrm{KA}_{12}(\mathrm{AlSi3O} 10)(\mathrm{F}, \mathrm{OH})_{2}$, potassium aluminium silicate hydroxide fluoride. Muscovite is not often valuable as a mineral specimen, but is often associated with other minerals of extraordinary beauty and value.

Iron oxides are minerals that are form by combination of cation with oxygen. These are in the category of non-silicate minerals. This mineral creates the reddish colour of the sludge. Iron hydrogen phosphate, $\mathrm{FeH}_{2} \mathrm{P}_{2} \mathrm{O}_{7}$ is a non-silicate mineral.

\subsection{Chemical Composition}

Chemical composition is vital because of its effect on the product behaviour. The chemical composition of water treatment sludge was determined by $\mathrm{x}$-ray fluorescence is shown in Table 1. Water treatment sludge is compared with clay. Water sludge has less $\mathrm{SiO}_{2} \operatorname{andK}_{2} \mathrm{O}$ than clay, but more $\mathrm{Al}_{2} \mathrm{O}_{3}$ and $\mathrm{Fe}_{2} \mathrm{O}_{3}$. Percentage of $\mathrm{Al}_{2} \mathrm{O}_{3}$ is highdue to coagulation process during water treatment process. Whereas, $\mathrm{Fe}_{2} \mathrm{O}_{3}$ is iron oxide which give the reddish colour of water sludge.

Table 1. Chemical composition of water treatment sludge (percentage)

\begin{tabular}{ccccccccccccc}
\hline Composition & $\mathrm{SiO}_{2}$ & $\mathbf{A l}_{2} \mathrm{O}_{3}$ & $\mathbf{F e}_{2} \mathrm{O}_{3}$ & $\mathbf{K}_{2} \mathbf{O}$ & $\mathbf{M g O}$ & $\mathbf{C a O}$ & $\mathbf{S O}_{3}$ & $\mathbf{P}_{2} \mathbf{O}_{5}$ & $\mathbf{T i O}_{2}$ & $\mathbf{M n O}$ & $\mathrm{ZrO}_{2}$ & $\mathbf{C r}_{3} \mathbf{O}_{3}$ \\
\hline Water Sludge & 51.76 & 36.70 & 6.67 & 2.68 & 0.70 & 0.52 & 0.38 & 0.24 & 0.11 & 0.06 & 0.05 & 0.05 \\
Clay [6] & 76.52 & 15.30 & 0.60 & 4.20 & 0.14 & 0.06 & NA & NA & 0.06 & NA & NA & NA \\
\hline
\end{tabular}

$\mathrm{SiO}_{2}$ (silicon dioxide, silica): Silica is found in nature in several forms, including quartz and opal. In fact, it has 17 crystalline forms. Silica is manufactured in several forms including as a major ingredient in Portland cement, glass, porcelain ceramic and is also used as a homeopathic remedy to treat impure blood, brittle nails and lack lustre hair [3].

$\mathrm{Al}_{2} \mathrm{O}_{3}$ (aluminium oxide, alumina): Alumina has a very high melting temperature and alumina ceramics can maintain up to $90 \%$ of their strength above $1100 \mathrm{C}$. They are thus employed in many refractory materials. Aluminium oxide is an excellent thermal and electrical insulator. 
In its crystalline form, called corundum, its hardness makes it suitable for use as an abrasive and as a component in cutting tools. Powdered aluminium oxide is frequently used as a medium for chromatography [3].

$\mathrm{Fe}_{2} \mathrm{O}_{3}$ (iron oxide, ferric oxide): Iron compounds are the most common colouring agent in ceramics. On one hand, they are nuisance impurities where they stain otherwise white clay or glaze or where they muddy an otherwise bright colour. Iron oxides, along with oxides of other metals, provide the colours in some glazes after being fired at a high temperature. They are also used as pigments [3].

$\mathrm{K}_{2} \mathrm{O}$ (potassium oxide): $\mathrm{K}_{2} \mathrm{O}$ is considered together with sodium, since the two almost always occur together and have very similar properties. When taken together, the two are often labelled $\mathrm{KNaO} . \mathrm{K}_{2} \mathrm{O}$ generally promotes higher melt viscosity than $\mathrm{Na}_{2} \mathrm{O}$. It is an important auxiliary flux in high temperature glazes. It is a heavy oxide and in general hosts the brightest colours of all fluxes except for lead. It is usually preferred even to soda for a more brilliant glossy glaze and longer firing range. $\mathrm{K}_{2} \mathrm{O}$ is considered as a very stable and predictable oxide [3].

$\mathrm{MgO}$ (magnesium oxide): is a white solid mineral that occurs naturally as periclase and is a source of magnesium is used by many libraries for preserving/deacidifying books and as an insulator in industrial cables. It is also used as a medication to relieve heartburn, sour stomach or acid indigestion. Medical uses of Magnesium oxide also include as a short-term laxative or used to supplement a diet with magnesium. Magnesium oxide is used as a basic refractory material for lining crucibles. Magnesium oxide is a principle ingredient in construction materials used for fireproofing. It is used as a reference white colour in colorimetric [3].

$\mathrm{CaO}$ (calcium oxide): Commonly known as lime, quicklime or burnt lime. It is also used in water and sewage treatment to reduce acidity, to soften as a flocculants and to remove phosphates and other impurities, in paper making to dissolve lignin as a coagulant and in bleaching, in agriculture to improve acidic soils and in pollution control, in gas scrubbers to desulphurize waste gases and to treat many liquid effluents. It is a refactory and a dehydrating agent and is used to purify citric acid, glucose, dyes and as a $\mathrm{CO}_{2}$ absorber. It is also used in pottery, concrete, paints and the food industry where it is sometimes used (in conjunction with water) to heat items like MREs (Meals Ready to Eat) and coffee [3]. 
$\mathrm{SO}_{3}$ (sulphur): $\mathrm{SO}_{3}$ refers to the sulphur material that burns away during firing. It can be used in an analysis to make clear the nature of LOI components. Since it is lost during firing, a formula weight of zero should be used so there is no impact on the calculated formula or calculated properties. Many raw clays contain some sulphur [3].

$\mathrm{P}_{2} \mathrm{O}_{5}$ (phosphorus pentoxide): Phosphorus along with calcium is an essential element in plant and animal growth, thus its principal source is organic ash (i.e. calcined cattle bones). Phosphoric oxide is normally present in only trace amounts in ceramic materials. Phosphorus pentoxide is an extremely good dehydrating agent. When combined with a carboxylic acid, the result is an anhydride. Phosphorite mineral $\mathrm{Ca}_{3}\left(\mathrm{PO}_{4}\right)_{2}$ and Apatite $3 \mathrm{Ca}_{3}\left(\mathrm{PO}_{4}\right)_{2} \mathrm{Ca}(\mathrm{Cl}, \mathrm{F})_{2}$ are the parent rocks of phosphate fertilizers [3].

$\mathrm{TiO}_{2}$ (titanium dioxide): $\mathrm{The} \mathrm{TiO}_{2}$ group is composed of rutile, anatase and brookite. This product is mainly for pottery-porcelain and enamel industry. Titanium dioxide $\left(\mathrm{TiO}_{2}\right)$ is a multifaceted compound. $\mathrm{TiO}_{2}$ is also a potent photocatalyst that can break down almost any organic compound when exposed to sunlight and a number of companies are seeking to capitalize on $\mathrm{TiO}_{2}$ 's reactivity by developing a wide range of environmentally beneficial products including self-cleaning fabrics, auto body finishes and ceramic tiles. Also, in development is a paving stone that uses the catalytic properties of $\mathrm{TiO}_{2}$ to remove nitrogen oxide from the air, breaking it down into more environmentally benign substances that can then be washed away by rainfall. Other experiments with $\mathrm{TiO}_{2}$ involve removing the ripening hormone ethylene from areas where perishable fruits, vegetables and cut flowers are stored; stripping organic pollutants such as trichloroethylene and methyl-tert-butyl ether from water and degrading toxins produced by blue-green algae. It remains to be seen, however whether the formation of undesirable intermediate products during these processes outweighs the benefits offered by $\mathrm{TiO}_{2}$ 's photocatalytic properties [3].

$\mathrm{MnO}$ (manganese oxide): Manganese is a constituent in many igneous rocks, and thus occurs in many clays weathered from these parent rocks [3].

$\mathrm{ZrO}_{2}$ (zirconium dioxide): Zirconium oxide is an extremely refractory material and its metallic form likewise melts very high. Zircon can be added to transparent glazes to produce a harder surface [3]. 


\subsection{Sample Selection}

In this research, sludge sample from water treatment plant were selected. A representative sample was taken and graded in size ranges of less than $425 \mu \mathrm{m}$. As a pilot study, this research only emphasize on the behaviour of sludge sample when mixed with Kaolin.

\subsection{Sample Preparation}

Wet sieve was used to make size fractions. Both samples, water sludge and clay were classified by using wet sieving method namely hydrometer test. For Atterberg limit test, water sludge which passed a $425 \mu \mathrm{m}$ test sieve was prepared to mix with clay weighing about $500 \mathrm{~g}$. The mixture was then added with distilled water to become a paste. Sample about $300 \mathrm{~g}$ from the paste was used for cone penetration test to get the liquid limit and the rest of the paste was used for plastic limit test.

\subsection{Moisture ContentandPlasticity}

Table 2. Moisture content of water sludge and clay

\begin{tabular}{ccc}
\hline Material & Water Sludge & Clay \\
\hline$(\%)$ & 47.7 & 17.69 \\
\hline
\end{tabular}

Table 3. Comparison of plasticity index for water sludge and the mixture of water sludge with

\begin{tabular}{|c|c|c|c|}
\hline Material & $\begin{array}{l}\text { Water } \\
\text { Sludge }\end{array}$ & $\begin{array}{c}20 \% \text { Clay }+ \\
80 \% \text { Water Sludge }\end{array}$ & $\begin{array}{c}\mathbf{5 0} \% \text { Clay }+ \\
\mathbf{5 0 \%} \text { Water Sludge }\end{array}$ \\
\hline Plastic Limit (\%) & 51.06 & 56.05 & 45.22 \\
\hline Liquid Limit (\%) & 77.3 & 57.34 & 52.32 \\
\hline Plasticity Index & 26.24 & 1.29 & 7.11 \\
\hline
\end{tabular}

Plasticity is very important in any ceramic product. Moisture content and plasticity behaviour for water treatment sludge when mixed with natural clay in this study is shown in Table 2 and Table 3 respectively. It is clearly shown that the plastic limit of the sample will increase after added with clay. Result in Fig. 5 shown that the plasticity index for raw water sludge is in the category of silt with high plasticity and the mixture of water sludge with $50 \%$ clay and $10 \%$ clay is in the category of silt with intermediate plasticity. Logical explanation for this is because water sludge is not clay even though kaolinite existed in the composition but kaolinite is the lowest category of clay. The content of silica is high and to increase the 
plasticity index for ceramic product need to add with high quality of clay. Calculation of the mixture is very important for good quality ceramic product.

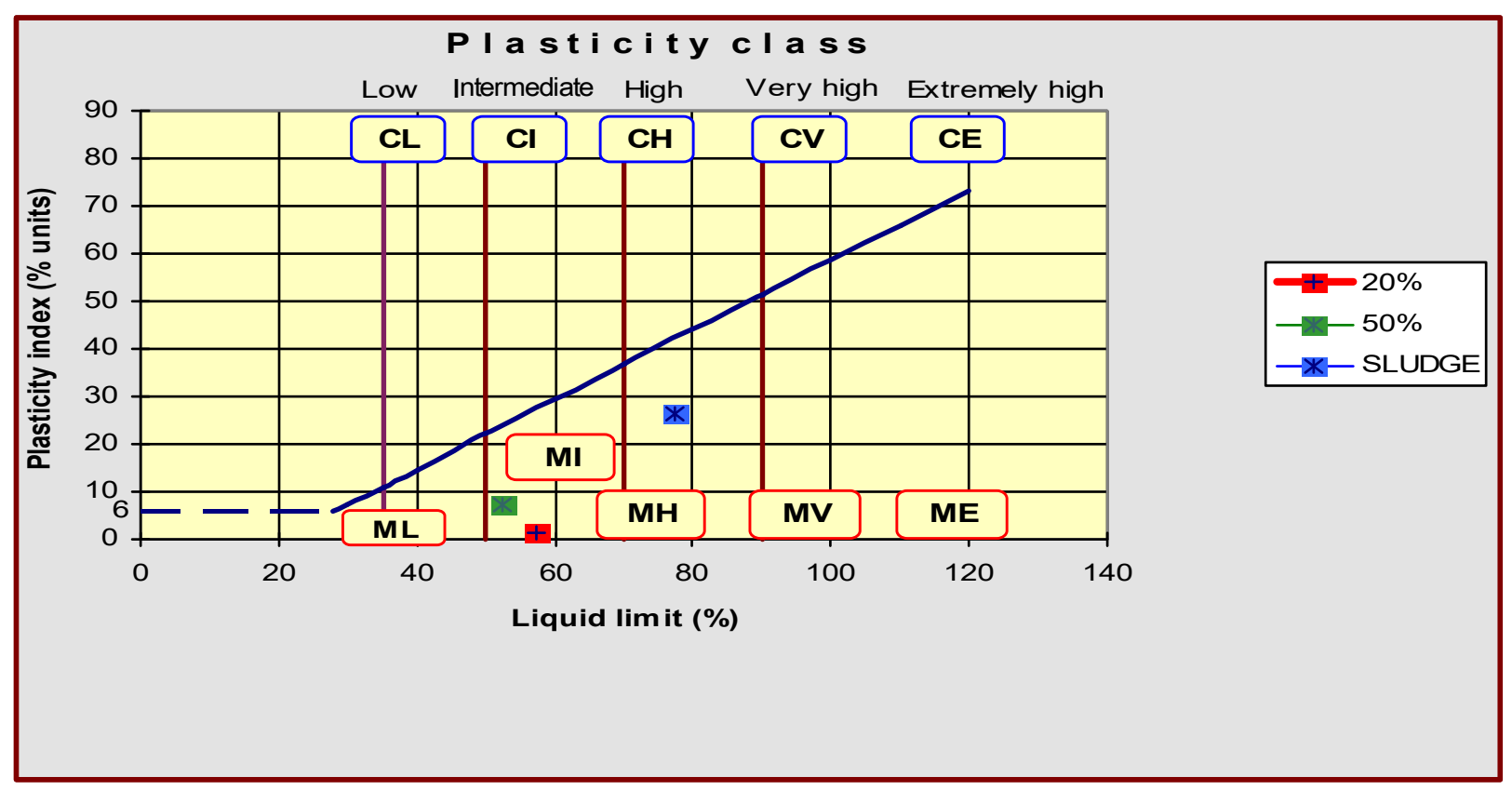

Fig.5. Plasticity index chart for different mixture of water sludge and clay

\section{CONCLUSION}

Sludge is a byproduct of water treatment process. It has always been considered as waste, which needs to be disposed with its associated costs. This paper has reviewed the potential of turning this waste into a resource. As a resource, it has potential to generate wealth from the resulting products. Apart from direct benefits, turning waste into wealth will also reduce disposal costs and eliminate the need for disposal sites, hence saving in land usage. Reduction in waste handling will definitely lead towards a more sustainable development, which is thus lead towards sustainable environment. Further study for producing water sludge as a construction material is recommended.

\section{REFERENCES}

[1] Standard British 1377. Methods of test for soils for civil engineering purposes. London: British Standards Institution, 1990

[2] Hamer F., Hamer J. The potter's dictionary of materials and techniques. Philadelphia: University of Pennsylvania Press, 2004 
[3] American Ceramic Society. Database and standards. 2015, http://ceramics.org/knowledge-center/databases-and-standards

[4] Machiavelli N. The Columbia electronic encyclopedia. New York: Columbia University Press, 2007

[5] Teixeira S R, de Souza S A, Moura C A. Mineralogical characterization of clays used in the structural ceramic industry in west of S. Paulo State, Brazil. Cerâmica, 2001, 47(304):204-207

[6] Thavornyutikarnc P, Phanichphantc S. Quality improvement of Lampang clay for porcelain bodies. ScienceAsia, 2002, 28:145-152

How to cite this article:

Azinoor Azida AB, Azida A, Wahid M A, Kamarudin F. The beneficial usage of water treatment sludge as pottery product. J. Fundam. Appl. Sci., 2017, 9(6S), 577-586. 